\title{
Incidence of Pigeon Circovirus in Eurasian Collared-Dove (Streptopelia decaocto) Detected by Nested PCR
}

\author{
O. KUBÍČEK, L. TARAS \\ Avian and Exotic Animal Clinic, University of Veterinary and Pharmaceutical Sciences Brno \\ Received March 23, 2005 \\ Accepted June 6, 2005
}

\begin{abstract}
Kubíček O., L.Taras: Incidence of Pigeon Circovirus in Eurasian Collared-Dove (Streptopelia decaocto) Detected by Nested PCR. Acta Vet. Brno 2005, 74: 361-368.

The paper describes the first demonstration of pigeon circovirus in Eurasian collared-dove (Streptopelia decaocto). Nested PCR was used to examine birds of the Columbiformes family. Pigeon circovirus DNA was identified in the bursa of Fabricius of an accidentally caught dove by nested PCR after the second reaction. Impaired feathers and other clinical signs observed could not, however, be attributed to circoviral infection.

The sequence of the amplified PCR product - middle of the capsid protein gene - was compared against all available circovirus sequences. Both the nucleotide and the derived amino acid sequence have a very close similarity to pigeon circovirus sequences. It may therefore be concluded that the sample was demonstrated to contain pigeon circovirus or another very similar virus. We therefore assume that pigeon circovirus may infect doves, too. Whether it is a special subtype or whether doves may be infected by common pigeon circovirus strains cannot be concluded with certainty from the existing results.
\end{abstract}

PCR, circovirus, pigeon, PiCV, Eurasian collared-dove, turtledove, Streptopelia decaocto

Members of the Circoviridae family are the smallest viruses known so far. Their genome comprising around 2,000 nucleotides is formed by single-stranded DNA protected by an icosahedral capside without envelope. As circoviruses mostly induce immune deficiency in birds, the clinical symptoms of infectious diseases are often accompanied by and overlap with secondary infections. Therefore circoviruses escaped attention until recently and their demonstration has been relatively new (Woods and Latimer 2000).

Their incidence is currently being demonstrated in an increasing number of avian species (Todd 2000). At the XIth International Congress of Virology held in Sydney in 1999, the Circoviridae family was divided into two genuses: Gyrovirus with Chicken infectious anaemia virus (CAV) and Circovirus (Pringle 1999). Genus Circovirus include two porcine ciroviruses Porcine circovirus 1 (PCV-1) and Porcine circovirus 2 (PCV-2) (Tischer et al. 1974; Meehan et al. 1998), and Beak and feather disease virus (BFDV) (Latimer et al. 1991). The newly identified avian circoviruses are pigeon circovirus (PiCV) (Mankertz et al. 2000), goose circovirus (GoCV) (Todd et al. 2001), canary circovirus (CaCV) (Phenix et al. 2001), and Duck circovirus (DuCV) (Hatterman et al. 2003).

The primary BFDV hosts include over 50 species of the Psittacidae family. The presence of nucleic acid of this virus has recently been demonstrated even in entirely unrelated species such as flightless birds (Ratitae): the ostrich (Struthio camelus), and songbirds (Passeriformes): mynah (Gracula sp.) (Eisenberg et al. 2003; Rahaus and Wolff 2003).

Among Streptopelia, illness caused by circovirus has been described in Streptopelia senegalensis (Pass et al. 1994). These doves had a feather illness bearing a close

\footnotetext{
Address for correspondence:

MVDr. Ladislav Taras

Avian and Exotic Animal Clinic

University of Veterinary and Pharmaceutical Sciences Brno

Palackého 1-3, 61242 Brno, Czech Republic
}

Phone +420 541562565

E-mail: TarasL@vfu.cz

http://www.vfu.cz/acta-vet/actavet.htm 
resemblance to the psittacine beak and feather disease (PBFD). Due to the fact that the feather illness in Streptopelia senegalensis resembled PBFD, the authors understandably believed that the birds might have been infected with BFDV. Haemagglutination and haemagglutination inhibitory testing helped to rule out BFDV as the etiological agent in feather disease in Streptopelia senegalensis (Raidal and Ridoch 1997). By electron microscopy, the feather homogenate of these birds was shown to contain circovirus-like particles sized $14-17 \mathrm{~nm}$. The authors therefore concluded that the circovirus is distinct from BFDV; the viral species has not been specified yet.

Pigeon circovirus has been identified in domestic pigeons (Columba livia domestica) only (Todd 2000). A circovirus infection was also confirmed by histology in two young wild wood doves (C. palumbus) (Dorrestein et al. 2001) and by histology and electron microscopy in Senegal doves (Streptopelia senegalensis) (Raidal and Ridoch 1997). The viral species has not been specified by genotyping and it is not known whether it is the species of circovirus infected domestic pigeons, too.

It is mainly young pigeons up to 6 months of age who are susceptible to pigeon circovirus infection. The affected birds show anorexia, lethargy, poor race results, diarrhoea, rapid loss of weight, and mortality (Paré et al. 1999). Although feather illness is not a common symptom of pigeon circovirus infection, a case involving a feather illness has been described, too (Woods et al. 2000). Presence of PiCV infection may be assumed already on the basis of anamnesis, clinical development in the flock, and evidence of specific intracytoplasmic botryoid inclusions in lymphoid tissue. The ultimate proofs include direct detection of PiCV by electron microscopy (Woods et al. 1993), by in situ hybridization (Smyth et al. 2001), and recently most often by PCR (Todd et al. 2001; 2002) or nested PCR (Soike et al. 2001; Taras et al. 2003).

\section{Materials and Methods}

In October 2004, a $130 \mathrm{~g}$ free-living Eurasian collared-dove (Streptopelia decaocto) with a spinal lesion and lesions in the breast muscles caused by mauling was presented at the Clinic of Avian, Reptilian, and Small Mammal Diseases. The dove had been found in Brno municipal area. The dove was killed by $\mathrm{T} 61^{\circledR}$ (Intervet, Unterschleissheim, Germany) due to a poor prognosis. A pathoanatomical examination using the methodology proposed by Dorrestein (1997) was made during which the macroscopically unchanged bursa of Fabricius was taken out to be subjected to nested PCR.

PCR

DNA isolation was performed using frozen samples of the bursa of Fabricius. An Invisorb Spin Tissue Mini Kit (Invitek Berlin) isolation set was employed. The first PCR reaction was performed on $2 \mu 1$ of DNA isolate, $7 \mu 1$ of distilled water, and $1 \mu 1$ of $25 \mathrm{pmol} / \mu 1$ primers and $10 \mu 1$ of Top-bio PPP Master Mix (Top-bio, Prague). The proof of PiCV DNA was based on primers from the C 1 ORF (open reading frame) region. The first PCR used Cir Sn 1206 (bases 1206 to 1226, 5'-GCAAAACACTGGTTACAATCC - 3') and Cir Asn 1917 (bases 1934 to 1917, 5'CAGGAGACGRAGGACACG - 3') primers selected based on the comparison of all three available pigeon circovirus sequences in the GenBank and the specificity of the PCR product was verified by comparison with the available sequences in the GenBank using BLAST (Basic Local Alignment Search Tool) software (Altschul et al. 1990).

The reaction ran for $4 \mathrm{~min}$ at $94{ }^{\circ} \mathrm{C}$, then for $30 \mathrm{~s}$ at $94{ }^{\circ} \mathrm{C}$, for $20 \mathrm{~s}$ at $49{ }^{\circ} \mathrm{C}, 35$ times for $45 \mathrm{~s}$ at $72{ }^{\circ} \mathrm{C}$, and for 8 $\min$ at $72{ }^{\circ} \mathrm{C}$. The second PCR used the primers Circo2Sn66 5'- GGGTCTGGTTGGGGTTGCAGG-3' and 5'CTTCCGCCTACGTCGCAAGGAC - 3'described above. (Taras et al. 2003).

The reaction solution contained $1 \mu \mathrm{l}$ of a $25 \mathrm{pmol} / \mu \mathrm{l}$ mixture of both primers, $9 \mu \mathrm{l}$ of re-distilled sterile water, $10 \mu \mathrm{l}$ of Top-bio PPP Master Mix, and $1 \mu \mathrm{l}$ of first PCR amplificates. The second reaction ran for $2 \mathrm{~min}$ at $94{ }^{\circ} \mathrm{C}$, then for $30 \mathrm{~s}$ at $94^{\circ} \mathrm{C}$, for $20 \mathrm{~s}$ at $65^{\circ} \mathrm{C}, 35$ times for $30 \mathrm{~s}$ at $72^{\circ} \mathrm{C}$ and for $8 \mathrm{~min}$ at $72^{\circ} \mathrm{C}$. The reaction was evaluated on $1.5 \%$ agar gel stained with ethidiumbromide. The size of the amplification product was compared against DNA using mass marker 2 -Log DNA Ladder (New England Biolabs). The presence of a fragment sized 522 bp was regarded as a positive result. Its specificity was verified by sequencing.

Sequencing

The PCR product nucleotides were sequenced in both directions by capillary electrophoresis with a laser detector at a MegaBACE 1000 genetic analyzer (Amersham Biosciences, Sunnyvale, CA, USA) in Genomac company, Prague. The sequencing used the primers Circo2Sn66 and Circo2Asn566 and marked terminators. 


\section{Results}

Basic post mortem findings

There was an area of $5 \mathrm{~cm}$ in diameter with no feathers on the back of the dove. The feather follicles present were damaged. There were lesions due to bites on the ventral side of the body, whose surroundings were contaminated with secretion. Half of the rectrices were missing. The remige were intact. The loss of feathers on the back and in the tail corresponded with an attack by a predator as for direction. Due to defecation problems caused by the spinal lesion, the area around the cloaca was contaminated with droppings. There were haemorrhages in the subcutis in the site of the lesion. A small lesion caused by a bite situated near the end of the sternum was identified on the left side of breast muscles; there was a lesion next to the shoulder joint on the right-hand side of the body. There were haemorrhages in the body cavity. The internal organs were free of macroscopic change. The spine was broken in the lumbar vertebrae area. The wounded dove was female.

PCR

The first PCR was negative even after DNA isolate concentration. After the second PCR a very strong amplified DNA fragment sized about $520 \mathrm{bp}$ was identified (Plate VII, Fig. 1). PCR product sequence $488 \mathrm{nt}$ (GenBank accession number AY887540) accorded nt 1366 - 1853 German isolate PiCV (GenBank accession number NC 002361) GGTAACTGAATGCGAGCCCATAGTGATTAACTTTCTGGGGAAACAAGCTGTT GCCTGATACCTGCAGTGGTATCCACTGGTTTCTCCCTGAGAACCATGTTGCTG CCGACTGGTTTGCCGTCGCCAGATCCGCGATTGTCAGTTGAGGTCGTGGCCTT ATGAGGCGTTTAAAGCCCTTTCTCAAATCCCATTTTCTGGCTCCGTCAAAGTC CATTAGGGGGTCATCTCCCAAGTCCACCTGCCCTTGAAAGGTTTTCAGCCTGG CATCATACATCGGGACAGTGTGCCCGAATCCTTTCCAGGTCGTGATGTCAACT CCTAGTGGTCTCATTTCCACCTTCACTAACGCAATTTGATAGTCCTCAAATGG GACTTTTAGCGTTGGCGCGTTGAGACCCACTGTGAGTACATCCGCCAGTTTGA ATGTAAATATGCCAGTACCGAATTTGAAATCATTGGTCGCTTGTTGCAATGTG ATCTTGTCCTTG

Verification of PCR product specificity

The sequence of the amplified product - nt 1366 - 1853 accorded German isolate PiCV (GenBank accession number NC 002361) was compared against available sequences in GenBanks using the Blast software. A high degree of homology with all available PiCV sequences was detected while homology with no another viral nucleic acid was detected. Further analysis revealed a 97\% homology with PiCV (Mankertz et al. 2000; accession no. NC 002361), 96\% with PiCV 9030, 93\% with PiCV 7050 (Todd et al. 2001; accession no. AJ298229 and AJ298230), and 90\% with PiCV SM 1 (Taras et al. 2003; accession no. AY461810) (Fig. 2).

Amino acid sequence of the derived hypothetic partial capside protein - 162 amino acid Position 46 - 207 of capsid protein of German isolate PiCV (accession no. NP 059530) KDKITLQQATNDFKFGTGIFTFKLADVLTVGLNAPTLKVPFEDYQIALVKVEMRP LGVDITTWKGFGHTVPMYDARLKTFQGQVDLGDDPLMDFDGARKWDLRKGFK RLIRPRPQLTIADLATANQSAATWFSGRNQWIPLQVSGNSLFPQKVNHYGLAFSY

Phylogenetic analysis

The PCR amplified fragment of circovirus DNA from the Eurasian collared-dove (ECD $\mathrm{CV}$ ) was compared to partial sequences of ORF C1 of the other circoviruses. The GenBank accession numbers and positions of compared parts are given in the legend to Table 1 . This comparison revealed the highest degree of homology with PiCV (Fig. 3). It is evident that 
Reference molecule:

$\begin{array}{lll}\text { Sequence } & 2: & \text { NC } 002361 \\ \text { Sequence } & 3: & \text { AJ 298229 } \\ \text { Sequence } & 4: & \text { AJ } 298230 \\ \text { Sequence } & 5: & \text { AY } 461810\end{array}$

$1-488-488$
$1-488$
$1-488$
$1-488$
$1-485$

Homology

\begin{tabular}{|c|c|}
\hline ECD CV & 1) \\
\hline NC 002361 & ( 1366$)$ \\
\hline AJ298229 & (1366) \\
\hline AJ298230 & ( 1365 ) \\
\hline AY 461810 & ( 1 ) \\
\hline $\mathrm{ECD} \quad \mathrm{CV}$ & 51) \\
\hline NC 002361 & ( 1416 ) \\
\hline AJ298229 & ( 1416 ) \\
\hline AJ298230 & ( 1415 ) \\
\hline AY 461810 & ( 48$)$ \\
\hline $\mathrm{ECD} \quad \mathrm{CV}$ & $(101)$ \\
\hline NC 002361 & (1466) \\
\hline AJ298229 & $(1466)$ \\
\hline AJ298230 & ( 1465 ) \\
\hline AY 461810 & ( 98) \\
\hline $\mathrm{ECD} C \mathrm{CV}$ & ( 151) \\
\hline NC 002361 & (1516) \\
\hline AJ298229 & ( 1516$)$ \\
\hline AJ 298230 & (1515) \\
\hline AY 461810 & ( 148$)$ \\
\hline $\mathrm{ECD} \quad \mathrm{CV}$ & ( 201) \\
\hline NC 002361 & ( 1566$)$ \\
\hline AJ 298229 & ( 1566$)$ \\
\hline AJ 298230 & (1565) \\
\hline AY 461810 & ( 198) \\
\hline $\mathrm{ECD} C \mathrm{CV}$ & ( 251) \\
\hline NC 002361 & (1616) \\
\hline AJ298229 & (1616) \\
\hline AJ298230 & ( 1615 ) \\
\hline AY 461810 & (248) \\
\hline $\mathrm{ECD} \quad \mathrm{CV}$ & $(301)$ \\
\hline NC 002361 & ( 1666$)$ \\
\hline AJ298229 & ( 1666$)$ \\
\hline AJ298230 & (1665) \\
\hline AY 461810 & (298) \\
\hline
\end{tabular}

GGTAACTGAATGCGAGCCCATAGTGATTAACTTTCTGGGGAAACAAGCTG

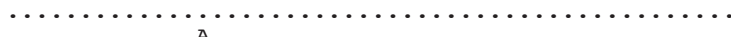

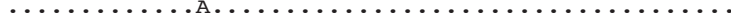

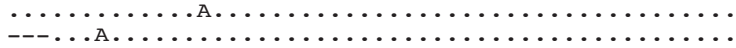

TTGCCTGATACСTGCAGTGGTATCCACTGGTTTCTCCCTGAGAACCATGT

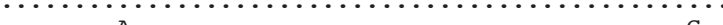
.............................

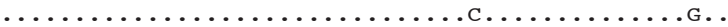

TGCTGCCGACTGGTTTGCCGTCGCCAGATCCGCGATTGTCAGTTGAGGTC

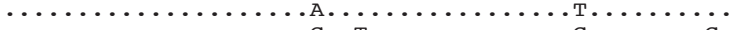
$\ldots \ldots \ldots \ldots \ldots \ldots \ldots$. . . . . . . . . . . . $\ldots \ldots \ldots \ldots \ldots \ldots$. . . . . . . . . . . . . . .

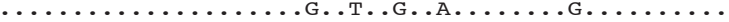

GTGGCCTTATGAGGCGTTTAAAGCССTTTCTCAAATCCСАTTTTCTGGCT

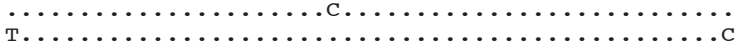

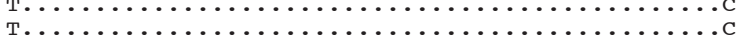

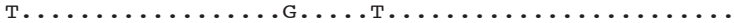

CCGTCAAAGTCCATTAGgGGGTCATCTCCCAAGTCCACСTGCССTTGAAA

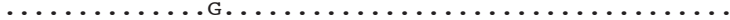

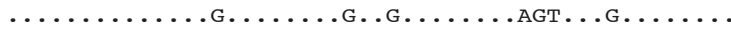
$\ldots \ldots \ldots \ldots \ldots$.................................

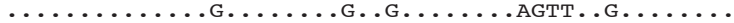

GGTTTTCAGCCTGGCATCATACATCGGGACAGTGTGCCCGAATCСTTTCC

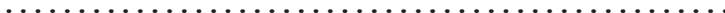
............................

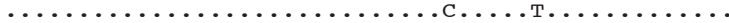

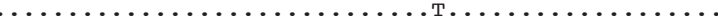

AGGTCGTGATGTCAACTCCTAGTGGTCTCATTTCCACСTTCACTAACGCA

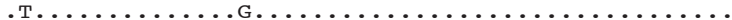

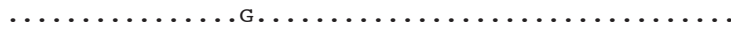
$\ldots \ldots \ldots \ldots \ldots \ldots \ldots \ldots \ldots \ldots \ldots \ldots \ldots \ldots$.

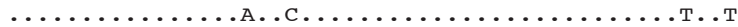

$\begin{array}{ll}\text { ECD CV } & (351) \\ \text { NC } 002361 & (1716) \\ \text { AJ 298229 } & (1716) \\ \text { AJ 298230 } & (1715) \\ \text { AY461810 } & (348)\end{array}$

АTTTGATAGTССтCAAATGGGACTTTTAGCGTTGGCGCGTTGAGACCCAC $\ldots$. .............. .............

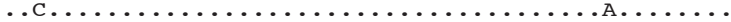

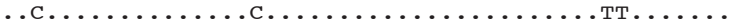
. C...............................

$\begin{array}{ll}\text { ECD CV } & (401) \\ \text { NC } 002361 & (1766) \\ \text { AJ298229 } & (1766) \\ \text { AJ298230 } & (1765) \\ \text { AY461810 } & (398) \\ \text { ECD CV } & (451) \\ \text { NC 002361 } & (1816) \\ \text { AJ298229 } & (1816) \\ \text { AJ298230 } & (1815) \\ \text { AY461810 } & (448)\end{array}$

TGTGAGTACATCCGCCAGTTTGAATGTAAATATGCCAGTACCGAATTTGA

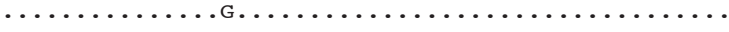

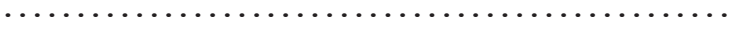

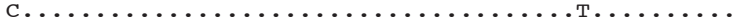

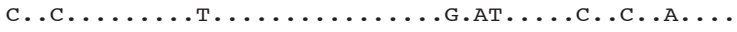

AATCATTGGTCGCTTGTTGCAATGTGATCTTGTCCTTG

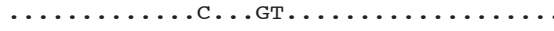

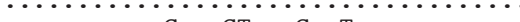
$\ldots \ldots \ldots$ .......... . СGT... . . .......

Fig. 2. Comparison of the sequence of the amplified fragment of circovirus DNA from the Eurasian collared-dove (ECD CV) (middle of capsid protein gene) against available PiCV sequences 


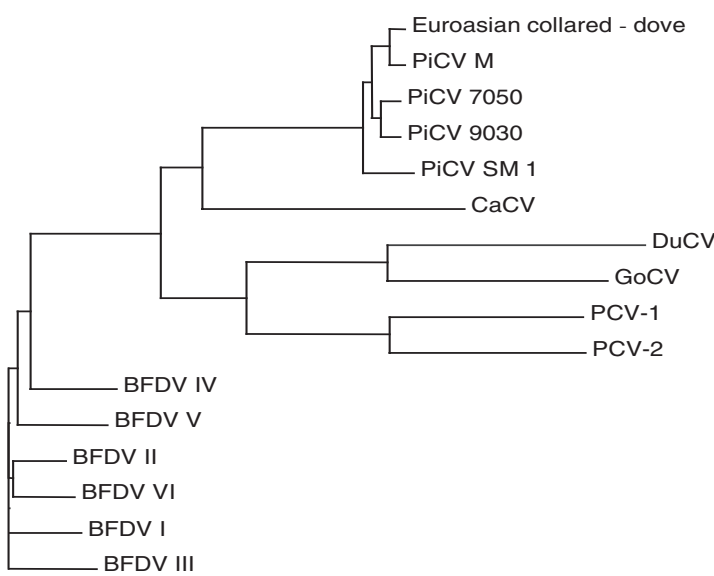

Fig. 3. Phylogram of Eurasian collared-dove CV (ECD CV), PiCV, CaCV, BFDV, GoCV, DuCV, PCV1 and PCV2 based on the partial sequences of ORF $\mathrm{C} 1$ corresponded to PCR amplified fragment of the Eurasian collareddove sample. The GenBank accession numbers and positions of compared parts are given in the legend to Table 1. The phylogram was generated from aligned, edited sequence data using the Align software (Vector)

the isolate shares the highest degree of homology with the German isolate whose accession number is NC 002361. Both of the Irish isolates 9030 and 7050 are characterized by a high degree of homology, too. The lowest degree of homology of EDC CV was confirmed with the South Moravian 1 isolate. There was a bigger genetic gap between the circovirus identified in the dove and other circoviruses than among PiCVs known as yet. As far as other circoviruses are concerned, the circovirus demonstrated by us is, like all other PiCV, genetically closest to $\mathrm{CaCV}$. Nevertheless, no conclusive homology with $\mathrm{CaCV}$ either was established using the Blast software. The comparison of derived amino acid sequences of the cap protein has led to similar results.

\section{Discussion}

The BLAST software has helped us to find a high degree of homology with PiCV only. No conclusive homology with any other circovirus including the most closely related canary circovirus has been identified. The constructed phylogenetic tree shows that the sequence of circoviral DNA isolated from an Eurasian collared-dove differed from the sequences of other pigeon circoviruses less than the variability between the PiCV described as yet. We therefore assume that we have demonstrated PiCV in the Eurasian collared-dove. Based on the high degree of homology with PiCV it may also be hypothesized that the circovirus was not a special subtype, but common PiCV infecting pigeons. Confirmation of this assumption will nevertheless require further data. It seems that we are not talking of another circovirus like those that they have recently been identified in geese (Todd et al. 2001), canaries (Phenix et al. 2001) and ducks (Hatterman et al. 2003), but of a finding that like BFDV, a known virus may infect further bird species.

Although feather illness is not a common sign of pigeon PiCV infection, such cases have already been reported in two young wild wood doves (C. palumbus) (Dorrestein et al. 2001), Senegal doves (Streptopelia senegalensis) (Raidal and Ridoch 1997) and in domestic pigeons (Woods et al. 2000). On the other hand, in these cases virus species have not been explicitly characterized by genotyping. It is not clear if these viruses agree with virus reported as PiCV. PiCV have not been demonstrated definitively in any free-living bird yet. One possible explanation is the one by Raidal and Riddoch (1997). According to these authors, infected birds become an easy prey to predators escaping thus examination. The lesions found in the dove we examined are a proof to this as the dove, too, has become a victim to a predator. Unlike previously detected circovirus infection in the Senegal dove 


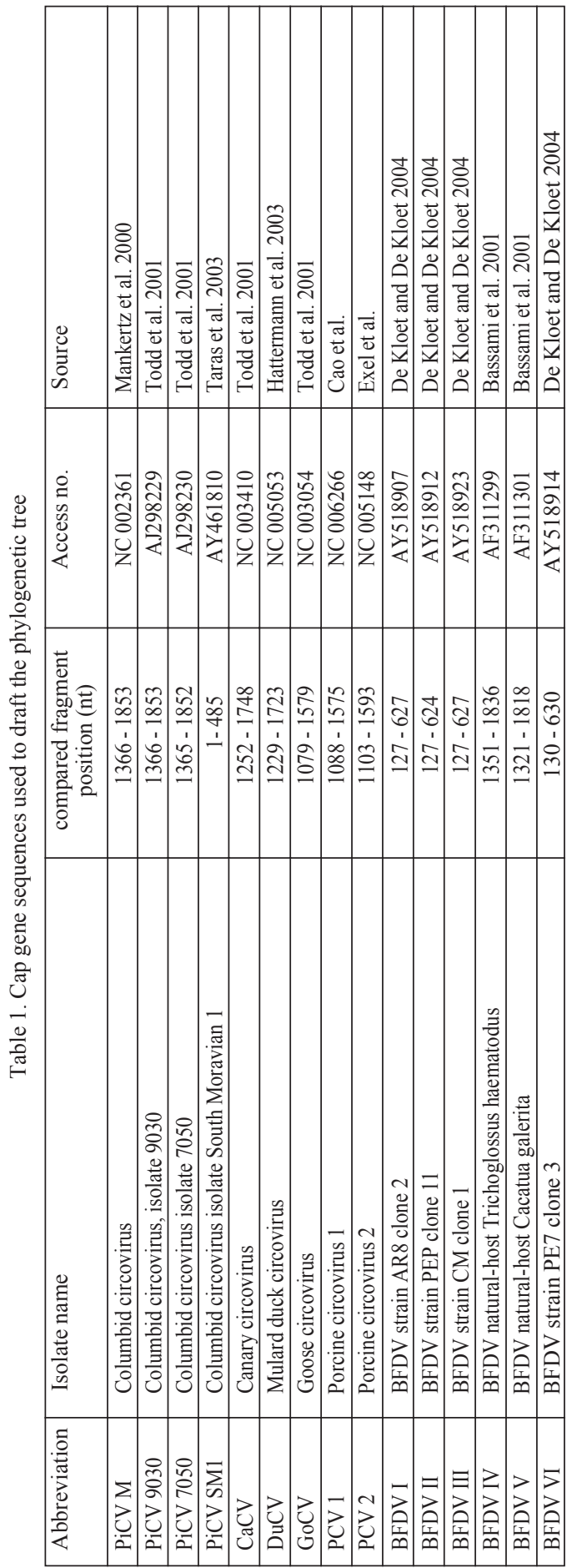

(Streptopelia senegalensis) (Raidal and Riddoch 1997), the Eurasian collared-dove examined by us was free of symmetric dystrophic change in feathers typical for PBFD. Severity and scope of clinical signs of circoviral infection nevertheless partly depend on the infected species (Dorrestein et al. 2001). The infection in the Eurasian collared-dove may have been in an initial stage and may have thus failed to show in the form of a feather illness.

Provided pigeon circovirus may infect the Eurasian collared-dove, the birds may be a reservoir of the virus in the wild. Free-living doves may therefore be one of the possible sources of infection of domestic pigeons.

\section{První průkaz přítomnosti holubího cirkoviru u hrdličky zahradní (Streptopelia decaocto ) metodou nested PCR}

Tato studie popisuje první průkaz holubího cirkoviru u hrdličky zahradní (Streptopelia decaocto). Metodou nested PCR byli vyšetřováni zástupci čeledi Columbiformes. U jedné náhodně odchycené poraněné hrdličky byla ve Fabriciově burze pomocí nested PCR po druhé reakci detekována prítomnost DNA holubího cirkoviru. Př́tomné poruchy opeření a ostatní klinické príznaky však nenaznačovaly cirkovirovou infekci. Sekvence amplifikovaného PCR produktu - střed kapsidového genu - byla porovnána se všemi dostupnými sekvencemi cirkovirů. Nukleotidová i odvozená aminokyselinová sekvence byla velmi podobná sekvencím holubího cirkoviru. Lze tak usuzovat, že ve vzorku byla prokázána př́tomnost holubího cirkoviru nebo velmi podobného viru. Předpokládáme proto, že holubí cirkovirus může infikovat i hrdličky. Zda se jedná o specielní subtyp, nebo zda běžný kmen holubího cirkoviru může infikovat hrdličky nelze $\mathrm{z}$ dosavadních výsledků jednoznačně určit. 


\section{Acknowledgment}

This work was supported by a Research Project of the Ministry of Education, Youth, and Sports of the Czech Republic (No. 161700002). The authors would like to thank Dr. D. Soike (Landeslabor Brandenburg, Potsdam, Germany) and Prof. Dr. Michael Hess (Clinic for Avian, Reptile and Fish Medicine, University of Veterinary Medicine, Vienna, Austria) for his valuable advise.

\section{References}

ALTSCHUL SF, GISH W, MILLER W, MYERS EW, LIPMAN DJ 1990: Basic local alignment search tool. J Mol Biol 215: 403-410

BASSAMI MR, YPELAAR I, BERRYMAN D, WILCOX GE, RAIDAL SR 2001: Genetic diversity of beak and feather disease virus detected in psittacine species in Australia. Virology 279:392-400

DE KLOET E, DE KLOET SR 2004: Analysis of the beak and feather disease viral genome indicates the existence of several genotypes which have a complex psittacine host specificity. Arch Virol 149:2393-412

DORRESTEIN GM 1997: Diagnostic Necropsy and Pathology. IN: ALTMAN RB (Ed): Avian Medicine and Surgery. W.B. Saunders, pp. 158-169

DORRESTEIN GM, SCHOEMAKER NJ, VAN DER HAGE MH, KIK MJ, VERSTAPPEN FALM, TONGEREN SE 2001: Circovirus infection in pet birds in the Netherlands: Clinical presentations and pathology. Proc. 6. European AVV-DVG Conference, 4. Scientific ECAMS Meeting, Avian Medicine and Surgery, Munich, Germany, March 7 - 10, 2001, p. 220-228

EISENBERG SW, VAN ASTEN AJ, VAN EDEREN AM, DORRESTEIN GM 2003: Detection of circovirus with a polymerase chain reaction in the ostrich (Struthio camelus) on a farm in The Netherlands. Vet Microbiol 95: $27-38$

HATTERMANN K, SCHMITT C, SOIKE D, MANKERTZ A 2003: Cloning and sequencing of Duck circovirus (DuCV). Arch Virol 148: 2471-2480

LATIMER KS, RAKICH PM, STEFFINS WL, KIRCHER IM, RITCHIE BW, NIAGRO FD, LUKERT PD 1991: A novel DNA virus associated with feather inclusions in psittacine beak and feather disease. Vet Pathol 28: 300-304

MANKERTZ A, HATTERMANN K, EHLERS B, SOIKE D 2000: Cloning and sequencing columbid circovirus (CoCV), a new circovirus from pigeons. Arch Virol 145: 2469-2479

MEEHAN BM, MCNEILLY F, TODD D, KENNEDY S, JEWHURST VA, ELLIS JA, HASSARD LE, CLARK EG, HAINES D, ALLAN GM 1998: Characterisation of novel circovirus DNAs associated with wasting syndromes in pig. J Gen Virol 79: 2171-2179

PARE J, BRASH ML, HUNTER DB, HAMPSON RJ 1999: Observations on pigeon circovirus infection in Ontario. Can Vet J 40: 659-662

PASS DA, PLANT SL, SEXTON N 1994: Natural infection of wild doves (Streptopelia senegalensis) with the virus of psittacine beak and feather disease. Aust Vet J 71: 307-308

PHENIX KV, WESTON JH, YPELAAR I, LAVAZZA A, SMYTH JA, TODD D, WILCOX GE, RAIDAL SR 2001: Nucleotide sequence analysis of a novel circovirus of canaries and its relationship to other members of the genus Circovirus of the family Circoviridae. J Gen Virol 82: 2805-2809

PRINGLE CR 1999: Virus Taxonomy at XIth International Congress of Virology, Sydney, Australia. Arch Virol 144: $2065-2070$

RAIDAL SR, RIDDOCH PA 1997: A feather disease in Senegal doves (Streptopelia senegalensis) morphologically similar to psittacine beak and feather disease. Avian Pathol 26: 829-836

RAHAUS M, WOLFF MH 2003: Psittacine beak and feather disease: a first survey of distribution of beak and feather disease virus inside the population of captive psittacine birds in Germany. J Vet Med B 50: 368-371

SHIVAPRASAD HL, CHIN RP, JEFFREY JS, LATIMER KS, NORDHAUSEN RW, NIAGRO FD, CAMPAGNOLI RP 1994 : Particles resembling circovirus in the bursa of Fabricius of pigeons. Avian Dis 38: $635-41$

SMYTH JA, WESTON J, MOFFETT DA, TODD D 2001: Detection of circovirus infection in pigeon by in situ hybridization using cloned DNA probes. J Vet Diagn Invest 13: 475-482

SOIKE D, HATTERMANN K, ALBRECHT K, SEGALES J, DOMINGO M, SCHMITT C, MANKERTZ A 2001: A diagnostic study on columbid circovirus infection. Avian Pathol 30: 605-611

TARAS L, KUBÍČEK O, JURANOVÁ R, JURAJDA V 2003: The first demonstration of pigeon cirkovirus infection in Czech Republic based on histology and nested PCR. Acta Vet Brno 72: 577-582

TISCHER I, RASCH R, TOCHTERMANN G 1974: Characterisation of papovavirus and picornavirus like particles in permanent pig kidney cell lines. Zentralbl Bakteriol Orig A 26: 153-167

TODD D 2000: Circoviruses: immunosuppressive threats to avian species: a review. Avian Pathol 29: $373-394$

TODD D, WESTON JH, BALL NW, BORGHMANS BJ, SMYTH JA, GELMINI L, LAVAZZA A 2001: Nucleotide sequence identification a novel circovirus from canaries. Avian Pathol 30: 321-325

TODD D, WESTON JH, SOIKE D, SMYTH JA 2001: Genome sequence determinations and analyses of novel circoviruses from goose and pigeon. Virology 286: 354-362 
TODD D, DUCHATEL JP, WESTON JH, BALL NW, BORGHMANS BJ, MOFFETT DA, SMYTH JA 2002: Evaluation polymerase chain reaction and dot blot hybridisation test in the diagnosis of pigeon circovirus infection. Vet Microbiol 89: 1-16

WOODS LW, LATIMER KS, BARR BC, NIAGRO FD, CAMPAGNOLI RP, NORDHAUSEN RW, CASTRO AE 1993: Circovirus-like infection in a pigeon. J Vet Diagn Invest 5: 609-612

WOODS LW, LATIMER KS 2000: Circovirus infection of nonpsittacine birds. J Avian Med Surg 14: 154 -163 
Plate VII

Kubíček O., Taras L.: Incidence ... pp. 361-368

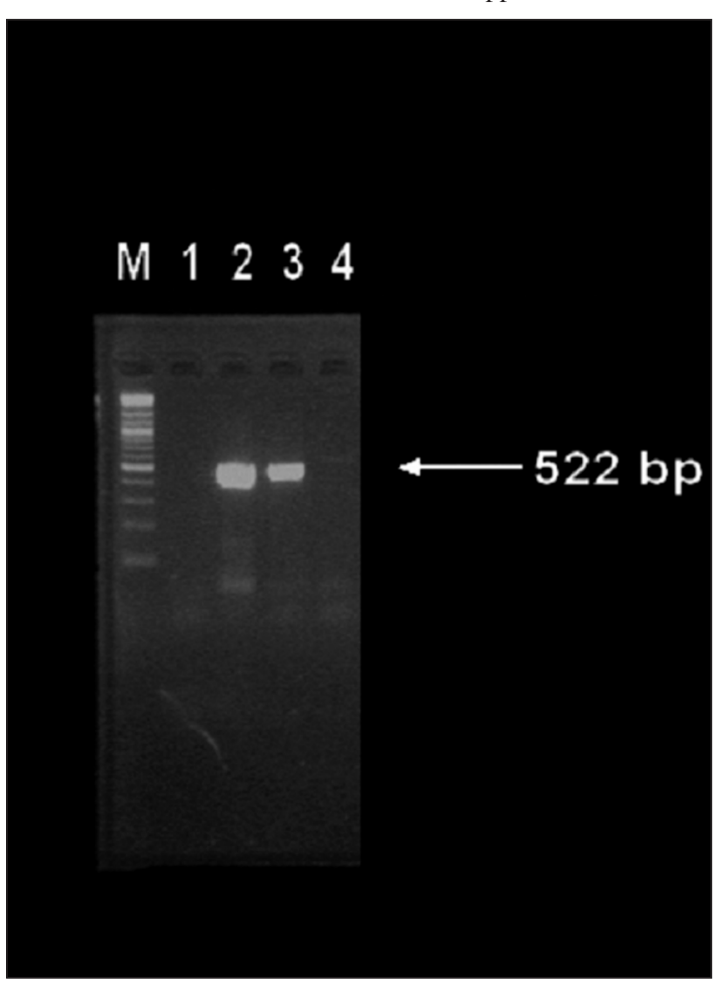

Fig.1. Detection of PiCV by nested PCR in sample of Eurasian collareddove BF. Lane M - mass marker 2-Log DNA Ladder (New England Biolabs), lane 1 - negative control sample, lane 2 - positive control sample, lane 3 - sample from BF of Eurasian collared-dove, lane 4 sample from $\mathrm{BF}$ of pigeon without $\mathrm{PiCV}$ 